gamma benzene hexachloride under similar conditions. The dusted wheat was contained in 2-oz. glass jars covered with organdie muslin and packed closely together in a wooden tray, $2 \frac{1}{2}$ in. deep. The experiment was conducted in a constant-temperature room having a small window facing north-east. Consequently, only very weak, diffuse light reached the dust scattered among the wheat grains.

Since the depth of the wheat in the jars was quite shallow, oxidation effects may have been of a higher order than that in the bags used by Beckley. Yet it is not likely that the oxygen content of the air within two or three inches of the surface of the bags, where insect infestation is usually high, would be much below that of the air outside.

Lehman's results with the beta isomer, quoted by Beckley, do not apply to the gamma isomer.

H. H. S. BovINGDON

Imperial Chemical Industries, Ltd.,

(Hawthorndale Laboratories),

Jealott's Hill Research Station, Bracknell, Berkshire.

\section{Trephocytes in Arbacia punctulata and their Role in Ovular Growth and in Respiration}

STUDIEs on tunicates, insects, annelids and the cœlenterate Tubularia ${ }^{\mathbf{1 , 2}}$ have revealed the presence of two main types of leucocytes in them : $(a)$ agranular, amceboid phagocytes, and $(b)$ granular, poorly or non-amœboid and non-phagocytic elements, for which I have proposed the term 'trephocytes'. In the organisms mentioned above, trephocytes frequently constitute 50-75 per cent of all leucocytes. Their inclusions are of a nutritive nature and are released into the blood, the tissues, or directly into other cells, a function referred to as 'trephocytosis'. Trephocytes are highly active in growth, and the study of trephocytosis proved instrumental in elucidating some of its manifestations and correlations.

Saint-Hilaire ${ }^{3}$ came close to similar conceptions with respect to conditions in sea-urchins. $\mathrm{He}$ distinguished sharply between their agranular phagocytes and the non-phagocytic granulocytes. The latter, however, were not found to be involved in nutritive processes, and a search for a possible role in the gonads proved negative, leading him to the assumption that the granulocytes take up metabolic

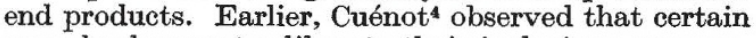
granular leucocytes liberate their inclusions, presumably originating in the digestive tract, throughout the organism. He was unaware of the specific character of these elements, and later ${ }^{5}$ abandoned his views as to the trophic nature of the granulocytes in favour of an excretory conception.

Our investigations on Arbacia have disclosed conditions similar to those found in other invertebrates studied. The trephocytes of this species also show characteristics generally found in these elements : large size; a small non-nucleolated nucleus, fragmented, pycnotic or missing in mature cells; and nutritive inclusions in the cytoplasm. These inclusions are liberated throughout the organism, the cell usually disintegrating during this process. No evidence was forthcoming indicating that the trephocytes are modified phagocytes, as claimed by Cuénot and others. During the period of investigation (June, July), the trephocytes in the perivisceral fluid were found to make up slightly more than 50 per cent of

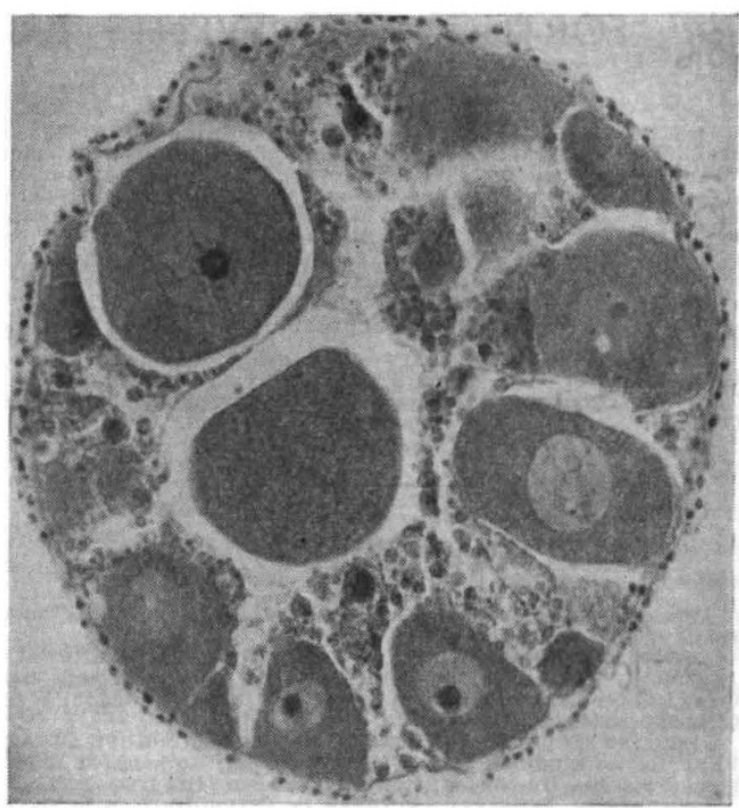

Cross-section of the ovary showing the interovular spaces filled with disintegrated trephocytes. The spaces around some oocytes are due to shrinkage caused by fixation

the total. As in some organs they comprise the only leucocytes present, their actual number in the organism may be considerably higher. Depending on the colour of the inclusions, the living trephocytes appear as green, red or colourless variants. Several characteristics suggest that the green kind represent the original form.

Contrary to the observations of Saint-Hilaire, the ovaries were found to be packed with numerous red and colourless trephocytes, most of them in an advanced state of disintegration (see illustration). Suitable preparations reveal that the young oocytes take up and assimilate the cellular inclusions and fragments of this brei. The quantity of material taken up appears to be considerable, suggesting that much of the ovular growth is due to substances derived from the trephocytes.

The red pigment of the trephocytes, named echinochrome by MaeMunn ${ }^{6}$, has been claimed to be an oxygen carrier ${ }^{6,7}$ or activator ${ }^{8,9}$, a view denied for the pure substance by Tyler ${ }^{10}$. McClendon ${ }^{11}$ found echinochrome in the test and eggs of Arbacia punctu. lata. Since the present study revealed that a considerable proportion of the material incorporated in the oocytes is derived from the red trephocytes, the possibility is not precluded that the echinochrome of the eggs is of the same origin.

New York Aquarium,

New York Zoological Society. March 21.

${ }^{1}$ Liebman, E., Growth, 10, 291 (1946).

${ }^{2}$ Liebman, E., Experientia, 3, 442 (1947).

${ }^{3}$ Saint-Hilaire, C., Trav. Soc. Imp. St.-Péterbourg, 27, 221 (1897).

${ }^{4}$ Cuénot, L., Arch. Zool., 9, 613 (1891).

${ }^{5}$ Cuénot, L., Arch. Anat. Micro., 1, 153 (1897).

- MacMunn, C. A., Quart. J. Micro. Sci., 25, 469 (1885).

${ }^{7}$ Griffiths, A. B., Proc. Roy. Soc., Edin., 19, 116 (1892).

${ }^{8}$ Cannan, R. K., Biochem. J., 21, 184 (1927).

' Friedheim, E. A. H., C.R. Soc. Biol., 111, 505 (1932).

${ }^{10}$ Tyler, A., Proc. U.S. Nat. Acad. Sci., 25, 523 (1939).

$"$ McClendon, J. F., J. Biol. Chem., 11, 435 (1912). 